\title{
Physiological responses of coastal and oceanic diatoms to diurnal fluctuations in seawater carbonate chemistry under two $\mathrm{CO}_{2}$ concentrations
}

\author{
Futian $\mathrm{Li}^{1}$, Yaping $\mathrm{Wu}^{1}$, David A. Hutchins ${ }^{2}$, Feixue $\mathrm{Fu}^{2}$, and Kunshan Gao ${ }^{1}$ \\ ${ }^{1}$ State Key Laboratory of Marine Environmental Science, Xiamen University, Xiamen 361102, China \\ ${ }^{2}$ Department of Biological Sciences, University of Southern California, Los Angeles, California, USA
}

Correspondence to: Kunshan Gao (ksgao@xmu.edu.cn)

Received: 6 July 2016 - Published in Biogeosciences Discuss.: 27 July 2016

Revised: 16 October 2016 - Accepted: 31 October 2016 - Published: 21 November 2016

\begin{abstract}
Diel and seasonal fluctuations in seawater carbonate chemistry are common in coastal waters, while in the open-ocean carbonate chemistry is much less variable. In both of these environments, ongoing ocean acidification is being superimposed on the natural dynamics of the carbonate buffer system to influence the physiology of phytoplankton. Here, we show that a coastal Thalassiosira weissflogii isolate and an oceanic diatom, Thalassiosira oceanica, respond differentially to diurnal fluctuating carbonate chemistry in current and ocean acidification (OA) scenarios. A fluctuating carbonate chemistry regime showed positive or negligible effects on physiological performance of the coastal species. In contrast, the oceanic species was significantly negatively affected. The fluctuating regime reduced photosynthetic oxygen evolution rates and enhanced dark respiration rates of $T$. oceanica under ambient $\mathrm{CO}_{2}$ concentration, while in the OA scenario the fluctuating regime depressed its growth rate, chlorophyll $a$ content, and elemental production rates. These contrasting physiological performances of coastal and oceanic diatoms indicate that they differ in the ability to cope with dynamic $p \mathrm{CO}_{2}$. We propose that, in addition to the ability to cope with light, nutrient, and predation pressure, the ability to acclimate to dynamic carbonate chemistry may act as one determinant of the spatial distribution of diatom species. Habitat-relevant diurnal changes in seawater carbonate chemistry can interact with OA to differentially affect diatoms in coastal and pelagic waters.
\end{abstract}

\section{Introduction}

Anthropogenic emissions of carbon dioxide $\left(\mathrm{CO}_{2}\right)$ since the Industrial Revolution have increased atmospheric $p \mathrm{CO}_{2} \mathrm{lev}$ els by $40 \%$ (Howes et al., 2015), mainly due to burning of fossil fuels and land use changes (Ciais et al., 2014). The oceans absorb about $30 \%$ of the $\mathrm{CO}_{2}$ emitted by human activities (Sabine et al., 2004), leading to decreases in $\mathrm{pH}$, concentration of carbonate ions, and saturation state of calcium carbonate, along with increases in the concentrations of aqueous $\mathrm{CO}_{2}$ and bicarbonate (i.e., ocean acidification). The global surface ocean mean $\mathrm{pH}$ has already decreased by about 0.1 units since the Industrial Revolution (Orr et al., 2005; Doney, 2010), and a further decrease of 0.3-0.4 units is expected to happen by 2100 under the "business-as-usual" scenario (Orr et al., 2005; Gattuso et al., 2015).

For marine organisms, the reduced seawater mean $\mathrm{pH}$ caused by ocean acidification (OA) could be detectable on a timescale of years to decades, while striking fluctuations in coastal seawater carbonate chemistry may occur over much shorter timescales in current and OA scenarios. The coastal zone plays a critical role in biogeochemical cycles and experiences great variability of physical and chemical factors (Drupp et al., 2011). In addition, it is the area most impacted by anthropogenic pressures (Gattuso et al., 1998). Carbonate chemistry in coastal seawater is affected by multiple drivers in addition to atmospheric $\mathrm{CO}_{2}$ dissolution, such as tidal cycles (Dai et al., 2009; Jiang et al., 2011; Wang et al., 2014), upwelling (Feely et al., 2008; Capone and Hutchins 2013), watershed processes, wind forcing (Drupp et al., 2011), anthropogenic nutrient inputs, aquaculture ac- 
tivities, and changes in ecosystem structure and metabolism (Duarte et al., 2013; Waldbusser and Salisbury 2014). Due to high biomass and sufficient or excess nutrients in coastal waters, biological activities alter $p \mathrm{CO}_{2}$, resulting in a diel cycle of $\mathrm{pH}$. The diel range of $\mathrm{pH}$ variation in some coastal ecosystems can be greater than $1 \mathrm{pH}$ unit (Duarte et al., 2013), which corresponds to a $900 \%$ change in $\mathrm{H}^{+}$concentration.

During a diurnal cycle, organisms in coastal areas could experience $\mathrm{pH}$ values that may be lower than the projected value for the surface ocean in the year 2100 (Hofmann et al., 2011; Hurd et al., 2011; Waldbusser and Salisbury, 2014). In contrast, $\mathrm{pH}$ in the open ocean is relatively stable, with a variation range of only $\sim 0.024$ over a month (Hofmann et al., 2011). Considering the lower buffering capacity in the OA scenario, $\mathrm{pH}$ variability would increase in both coastal and oceanic waters (Egleston et al., 2010; Cai et al., 2011; Denman et al., 2011; Wang et al., 2013). The amplitude of $\mathrm{pH}$ variation in coastal water will be larger than in oceanic water due to the presence of multiple drivers (Waldbusser and Salisbury, 2014). For instance, biological activities could increase variation in $\mathrm{pH}$ up to $40 \%$ compared to the present extent of variation under elevated $p \mathrm{CO}_{2}$ conditions in coastal waters (Egleston et al., 2010).

Responses of fish (Dixon, 2014), gastropods (Onitsuka et al., 2014), oysters (Keppel, 2015), mussels (Frieder et al., 2014), coral (Dufault et al., 2012; Comeau et al., 2014), canopy-forming kelp (Britton et al., 2016), and coralline algae (Gao et al., 1993; Cornwall et al., 2013; Noisette et al., 2013; Johnson et al., 2014) to diurnally fluctuating $p \mathrm{CO}_{2} / \mathrm{pH}$ have been studied recently. Dufault et al. (2012) hypothesized that storage of dissolved inorganic carbon during the nighttime high- $p \mathrm{CO}_{2}$ period fueled daytime calcification (and perhaps photosynthesis), resulting in higher calcification and survival rate of coral recruits. Thus, it appears that some marine organisms may benefit from $p \mathrm{CO}_{2}$ fluctuations. In spite of this body of literature, the responses of marine phytoplankton to fluctuating $\mathrm{pH} / p \mathrm{CO}_{2}$ are still unclear. To our knowledge, only one study has addressed the responses of the marine green alga Ostreococcus to fluctuating $p \mathrm{CO}_{2}$ (Schaum et al., 2016). However, how $\mathrm{CO}_{2}$ variability affects other major marine phytoplankton groups over either the short or long term remains unknown.

Coastal and open-ocean species are distinguished by habitat-related differences in cell size, nutrient utilization (Glibert and Ray, 1990), photosynthetic architecture (Strzepek and Harrison, 2004), and photosynthetic performance (Lavaud et al., 2007; Li et al., 2011; Liu and Qiu, 2012). Our study was intended to understand whether coastal and oceanic species also differ in their capacity to respond to fluctuating carbonate chemistry. A coastal Thalassiosira weissflogii isolate and an oceanic diatom, Thalassiosira oceanica, were used in the present study. We manipulated $p \mathrm{CO}_{2}$ to mimic diurnally fluctuating carbonate chemistry and hypothesized that coastal diatoms would show better physiological performance under fluctuating carbonate chemistry than oceanic ones, a difference that could potentially be a key factor influencing the geographical distribution of diatoms.

\section{Materials and methods}

\subsection{Cultures and experimental setup}

Thalassiosira weissflogii (CCMP 1336, isolated from coastal Long Island, New York, USA, in 1956) and Thalassiosira oceanica (CCMP 1005, isolated from the Sargasso Sea in 1958) were incubated in Aquil medium (Sunda et al., 2005). Triplicate cultures (incubated in $1 \mathrm{~L}$ autoclaved Erlenmeyer flasks) were used for each treatment, illuminated by cool white fluorescent light at an intensity of $115 \mu \mathrm{mol}$ photons $\mathrm{m}^{-2} \mathrm{~s}^{-1}$. Cultures were maintained at $20^{\circ} \mathrm{C}$ with a $12 \mathrm{~h}: 12 \mathrm{~h}$ light and dark cycle. Cells were maintained at exponential growth phase with maximal concentration $<1.1 \times 10^{4} \mathrm{~mL}^{-1}$ (T. weissflogii) or $3.5 \times 10^{4} \mathrm{~mL}^{-1}(T$. oceanica) in semi-continuous cultures (cultures were diluted every $24 \mathrm{~h}$ at $6 \mathrm{~h}$ after the onset of light).

T. weissflogii and T. oceanica were acclimated to four treatments: (1) steady carbonate chemistry at ambient $p \mathrm{CO}_{2}$ level (LCs); (2) diurnally carbonate chemistry fluctuating around ambient $p \mathrm{CO}_{2}$ level (LCf); (3) steady carbonate chemistry at elevated $p \mathrm{CO}_{2}$ level (HCs); and (4) diurnally carbonate chemistry fluctuating around elevated $p \mathrm{CO}_{2}$ level (HCf) for 15 generations before sampling. Steady regimes were bubbled with ambient air $(400 \pm 15 \mu \mathrm{atm}, \mathrm{LCs})$ or elevated $(1005 \pm 40 \mu \mathrm{atm}, \mathrm{HCs}) \quad p \mathrm{CO}_{2}$, which was automatically achieved by mixing air/ $\mathrm{CO}_{2}$ with a $\mathrm{CO}_{2}$ enricher (CE100B, RuiHua). The fluctuating regimes were obtained by changing the $\mathrm{CO}_{2}$ partial pressure every $12 \mathrm{~h}$. Cells were aerated with air of low $p \mathrm{CO}_{2}$ (i.e., 0 or $557 \pm 15 \mu \mathrm{atm}$ for LCf and $\mathrm{HCf}$, respectively) during the photoperiod; the aeration was changed to high $p \mathrm{CO}_{2}$ (i.e., $870 \pm 19$ or $1949 \pm 35 \mu \mathrm{atm}$ for LCf and HCf, respectively) at the beginning of the dark period. Measurements showed that $\mathrm{pH}$ gradually increased and decreased, similar to a natural diurnal cycle (see Results). Since pH increased quickly in the first few hours of the photoperiod, the aeration rates were adjusted to make sure the fluctuating regimes reached similar $\mathrm{pH}$ values with corresponding steady regimes in the middle of photoperiod and reached target values at the end of photoperiod. The steady regimes were aerated with stable $p \mathrm{CO}_{2}$ air at the same flow rate as the fluctuating regimes. The $\mathrm{pH}$ was measured every $1.5 \mathrm{~h}$ by a $\mathrm{pH}$ meter (Orion $2 \mathrm{STAR}$, Thermo Scientific) calibrated with standard National Bureau of Standards (NBS) buffers. Samples for total alkalinity (TA) measurement were poisoned with a saturated solution of mercuric chloride after filtration. TA was determined by Gran acidimetric titration with a TA analyzer (AS-ALK1+, Apollo SciTech). Certified reference materials obtained from A. G. Dickson at the Scripps Institution of Oceanography were used to assure the 
accuracy of the TA measurement. TA and $\mathrm{pH}$ were applied to CO2SYS software to calculate other carbonate chemistry parameters (Table 1). Subsamples for measurement of physiological parameters were always taken in the middle of the photoperiod ( $6 \mathrm{~h}$ after the onset of light), unless otherwise noted.

\subsection{Growth rate and chlorophyll $a$ content}

Cell concentration and mean cell size were measured by a Coulter particle count and size analyzer (Z2, Beckman Coulter). Specific growth rate was calculated according to the equation $\mu=\left(\operatorname{lnN}_{1}-\ln \mathrm{N}_{0}\right) /\left(t_{1}-t_{0}\right)$, in which $\mathrm{N}_{1}$ and $\mathrm{N}_{0}$ represent cell concentrations at $t_{1}$ and $t_{0}$. For the chlorophyll $a$ content determination, samples were filtered onto $\mathrm{GF} / \mathrm{F}$ filters ( $25 \mathrm{~mm}$, Whatman) and extracted overnight at $4{ }^{\circ} \mathrm{C}$ in absolute methanol before centrifugation. The supernatants were analyzed by a UV-VIS spectrophotometer (DU800, Beckman Coulter) and the chlorophyll $a$ content was calculated according to the equation of Ritchie (2006).

\subsection{Elemental composition and production rate}

Samples for measuring particulate organic carbon (POC) and nitrogen (PON) were filtered onto pre-combusted $\left(450{ }^{\circ} \mathrm{C}\right.$ for $6 \mathrm{~h}) \mathrm{GF} / \mathrm{F}$ filters $(25 \mathrm{~mm}$, Whatman). Filters were treated using $\mathrm{HCl}$ fumes to remove any inorganic carbon and dried before analysis on a CHNS/O analyzer (2400 Series II, PerkinElmer). Polycarbonate filters (1.2 $\mu \mathrm{m}$ pore size) were used to determine biogenic silica (BSi) by the spectrophotometric method of Brzezinski and Nelson (1995). Production rates of POC, PON, and BSi were calculated by multiplying cellular content by specific growth rate.

\subsection{Chlorophyll $a$ fluorescence}

The photochemical parameters were determined using a xenon-pulse amplitude modulated fluorometer (Xe-PAM, Walz). Effective photochemical quantum yields were determined according to the equation of Genty et al. (1989): $\Phi_{\mathrm{PSII}}=\left(F_{\mathrm{m}}^{\prime}-F_{\mathrm{t}}\right) / F_{\mathrm{m}}^{\prime}=\Delta F / F_{\mathrm{m}}^{\prime}$ for light-adapted samples, where $F_{\mathrm{m}}^{\prime}$ indicates maximum chlorophyll fluorescence of light-adapted samples and $F_{\mathrm{t}}$ indicates steady chlorophyll fluorescence of light-adapted samples. Non-photochemical quenching (NPQ) was calculated as $\mathrm{NPQ}=\left(F_{\mathrm{m}}-F_{\mathrm{m}}^{\prime}\right) / F_{\mathrm{m}}^{\prime}$, where $F_{\mathrm{m}}$ indicates maximum chlorophyll fluorescence of dark-adapted samples. $\Phi_{\text {PSII }}$ and NPQ were measured under actinic light intensity $\left(\sim 156 \mu \mathrm{mol}\right.$ photons $\left.\mathrm{m}^{-2} \mathrm{~s}^{-1}\right)$ similar to culture light level after $10 \mathrm{~min}$ of dark adaptation. Given the changing carbonate chemistry over a diurnal cycle, $\Phi_{\text {PSII }}$ and NPQ were determined at three time points: $0.5,6$, and $11.5 \mathrm{~h}$ after the onset of light.

\subsection{Photosynthetic oxygen evolution and dark respiration rates}

Net photosynthetic oxygen evolution and dark respiration rates were determined using a Clark-type oxygen electrode (Oxygraph, Hansatech) at the experimental temperature. Oxygen evolution rates were measured under $115 \mu \mathrm{mol}$ photons $\mathrm{m}^{-2} \mathrm{~s}^{-1}$ at the same three time points as mentioned above. Oxygen consumption rates were measured in the middle of photoperiod ( $6 \mathrm{~h}$ after the onset of light), when the steady and fluctuating regimes reached similar $\mathrm{pH}$ values. Samples were gently filtered $(<0.02 \mathrm{MPa})$ onto $47 \mathrm{~mm}$ cellulose acetate membranes, and then re-suspended into $20 \mathrm{mmol} \mathrm{L}^{-1}$ Tris-buffered medium. The re-suspended cells were injected into an oxygen electrode chamber equipped with a magnetic stirrer. Rates of oxygen evolution and consumption were derived from the linear portion of the slope of the oxygen record ( $\sim 10 \mathrm{~min}$ per sample). The $\mathrm{pH}$ values of Tris-buffered media were pre-adjusted to their corresponding culture media values. That is, $\mathrm{pH}$ values of Tris-buffered media of the three time points in the LCf treatment were 7.84, 8.14 , and 8.35, and those in the HCf treatment were 7.54, 7.80, and 8.06. Values in the LCs and HCs treatments were set to 8.14 or 7.80 for all three time points, respectively.

\subsection{Statistical analyses}

Data were analyzed by a two-way analysis of variance (ANOVA) with $p \mathrm{CO}_{2}$ level and $p \mathrm{CO}_{2}$ variability classed as factors in the model, each with two levels $(400 \pm 15 \mu$ atm and $1005 \pm 40 \mu \mathrm{atm}$, two levels of $p \mathrm{CO}_{2}$; steady and fluctuating regimes for two levels of $p \mathrm{CO}_{2}$ variability, respectively). The interaction of the two factors was also included in the model. All data used for ANOVA analysis were tested for normality (Shapiro-Wilk test) and homogeneity of variances (Levene test). When $p$ values were under 0.05 , the post hoc Duncan test was used to determine the differences between treatments. All data are reported as the mean value of triplicate cultures \pm standard deviation (SD).

\section{Results}

\subsection{Variation of $\mathrm{pH}$ in experimental regimes}

The variation ranges of $\mathrm{pH}$ in the LCf and $\mathrm{HCf}$ treatments were $0.52 \pm 0.03$ and $0.53 \pm 0.03$, respectively. At the beginning of the photoperiod, $\mathrm{pH}$ of the LCf regime was $7.84 \pm 0.02$ (Fig. 1), and then it increased to $8.15 \pm 0.03$ at $6 \mathrm{~h}$ after the onset of light, similar to the value of the $\mathrm{LCs}$ regime $(8.13 \pm 0.02)$. The $\mathrm{pH}$ value of the $\mathrm{LCf}$ regime reached $8.35 \pm 0.02$ at $12 \mathrm{~h}$ after the onset of light, and then decreased to $7.84 \pm 0.02$. For the $\mathrm{HCf}$ regime, $\mathrm{pH}$ ranged from $7.54 \pm 0.01$ to $8.06 \pm 0.02$ and reached $7.82 \pm 0.01$ at $6 \mathrm{~h}$ after the onset of light, similar to the value of the HCs regime $(7.79 \pm 0.01)$. 
Table 1. Carbonate chemistry parameters of culture media before and after dilution under steady and fluctuating regimes of ambient (LC) and elevated ( $\mathrm{HC}) p \mathrm{CO}_{2}$ levels. Values are means $\pm \mathrm{SD}$ of triplicate cultures. The different superscripted letters indicate significant $(p<0.05)$ differences among treatments.

\begin{tabular}{lrrrrrr}
\hline & $\mathrm{pH}_{\mathrm{NBS}}$ & $\begin{array}{r}\mathrm{TA} \\
\left.(\mu \mathrm{mol} \mathrm{kg})^{-1}\right)\end{array}$ & $\begin{array}{r}\mathrm{DIC} \\
\left(\mu \mathrm{mol} \mathrm{kg}{ }^{-1}\right)\end{array}$ & $\begin{array}{r}\mathrm{HCO}_{3}^{-} \\
\left.(\mu \mathrm{mol} \mathrm{kg})^{-1}\right)\end{array}$ & $\begin{array}{r}\mathrm{CO}_{3}^{2-} \\
\left.(\mu \mathrm{mol} \mathrm{kg})^{-1}\right)\end{array}$ & $\begin{array}{r}\mathrm{CO}_{2} \\
\left(\mu \mathrm{mol} \mathrm{kg}{ }^{-1}\right)\end{array}$ \\
\hline After dilution & & & & & & \\
LCs & $8.12 \pm 0.03^{\mathrm{a}}$ & $2397 \pm 7^{\mathrm{a}}$ & $2132 \pm 20^{\mathrm{a}}$ & $1929 \pm 27^{\mathrm{a}}$ & $188 \pm 8^{\mathrm{a}}$ & $16 \pm 1^{\mathrm{a}}$ \\
LCf & $8.13 \pm 0.01^{\mathrm{a}}$ & $2398 \pm 2^{\mathrm{a}}$ & $2128 \pm 6^{\mathrm{a}}$ & $1922 \pm 10^{\mathrm{a}}$ & $191 \pm 4^{\mathrm{a}}$ & $15 \pm 1^{\mathrm{a}}$ \\
HCs & $7.80 \pm 0.02^{\mathrm{b}}$ & $2392 \pm 5^{\mathrm{a}}$ & $2279 \pm 10^{\mathrm{b}}$ & $2144 \pm 12^{\mathrm{b}}$ & $98 \pm 3^{\mathrm{b}}$ & $37 \pm 1^{\mathrm{b}}$ \\
HCf & $7.80 \pm 0.02^{\mathrm{b}}$ & $2406 \pm 13^{\mathrm{a}}$ & $2288 \pm 19^{\mathrm{b}}$ & $2152 \pm 20^{\mathrm{b}}$ & $100 \pm 3^{\mathrm{b}}$ & $36 \pm 2^{\mathrm{b}}$ \\
\hline Before dilution & & & & & & \\
LCs & $8.13 \pm 0.02^{\mathrm{a}}$ & $2399 \pm 2^{\mathrm{a}}$ & $2133 \pm 7^{\mathrm{a}}$ & $1929 \pm 12^{\mathrm{a}}$ & $189 \pm 5^{\mathrm{a}}$ & $15 \pm 1^{\mathrm{a}}$ \\
LCf & $8.14 \pm 0.02^{\mathrm{a}}$ & $2388 \pm 19^{\mathrm{a}}$ & $2116 \pm 21^{\mathrm{a}}$ & $1910 \pm 22^{\mathrm{a}}$ & $191 \pm 5^{\mathrm{a}}$ & $15 \pm 1^{\mathrm{a}}$ \\
HCs & $7.79 \pm 0.02^{\mathrm{b}}$ & $2401 \pm 6^{\mathrm{a}}$ & $2287 \pm 7^{\mathrm{b}}$ & $2153 \pm 8^{\mathrm{b}}$ & $98 \pm 4^{\mathrm{b}}$ & $37 \pm 2^{\mathrm{b}}$ \\
HCf & $7.82 \pm 0.01^{\mathrm{b}}$ & $2408 \pm 9^{\mathrm{a}}$ & $2283 \pm 12^{\mathrm{b}}$ & $2144 \pm 13^{\mathrm{b}}$ & $104 \pm 2^{\mathrm{b}}$ & $34 \pm 1^{\mathrm{b}}$ \\
\hline
\end{tabular}

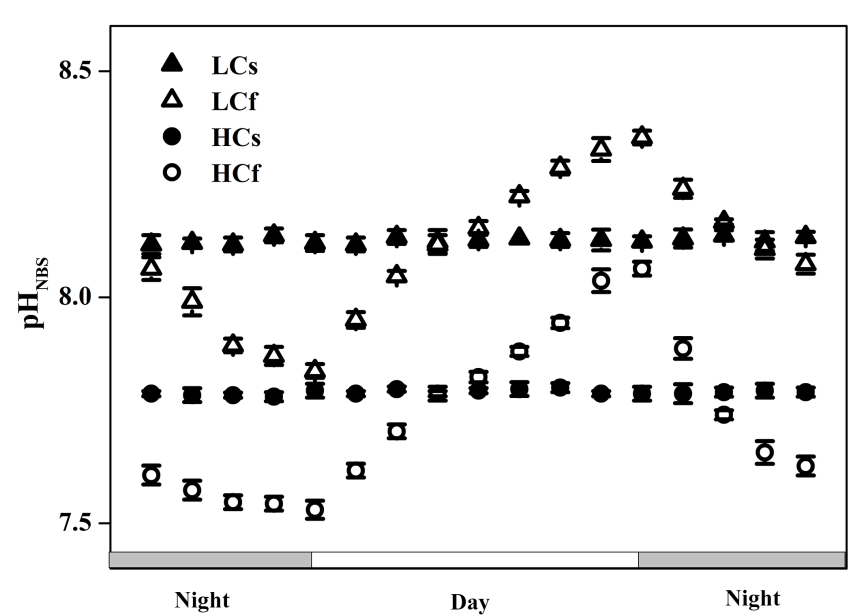

Figure 1. Measured $\mathrm{pH}_{\mathrm{NBS}}$ variation over a diel cycle in the four experimental treatments (LCs, closed triangles; LCf, open triangles; $\mathrm{HCs}$, closed circles; $\mathrm{HCf}$, open circles). Here $\mathrm{pH}$ values of triplicate cultures in one experimental day are shown.

\subsection{Specific growth rate and mean cell size}

Growth rates of $T$. weissflogii were not influenced by diurnally fluctuating carbonate chemistry in either the current or the OA scenario (Fig. 2a). No effects of OA on growth rate of $T$. weissflogii were detected. There were no differences in growth rates between the steady and fluctuating regimes for T. oceanica under the ambient $p \mathrm{CO}_{2}$ condition (Fig. 2b). However, the fluctuating regime reduced its growth rate by $9 \%$ under the elevated $p \mathrm{CO}_{2}$ condition. OA influenced the growth rate of $T$. oceanica, with rates of HCs cells being $16 \%$ lower than those of LCs cells. A significant interaction between $p \mathrm{CO}_{2}$ level and $p \mathrm{CO}_{2}$ variability on growth rate of T. oceanica was found.
Mean cell sizes were not affected by the fluctuating treatment under either ambient or elevated $p \mathrm{CO}_{2}$ conditions in T. weissflogii (Table 2). T. oceanica cells showed minor but significant changes in cell size in the fluctuating treatments. Cells in the LCf treatment cells were $1.2 \%$ larger than LCs cells, while HCf cells were $1.4 \%$ smaller than cells in the corresponding steady treatments, resulting in a significant interaction between $p \mathrm{CO}_{2}$ level and $p \mathrm{CO}_{2}$ variability.

\subsection{Chlorophyll $a$ content and elemental composition}

Chlorophyll $a$ contents of $T$. weissflogii in the four treatments were not significantly different. For T. oceanica, the fluctuating regime did not influence chlorophyll $a$ content under ambient $\mathrm{CO}_{2}$ level. However, in the HCf treatment chlorophyll $a$ content decreased by $24 \%$ compared to the steady regime (Table 2). A significant interaction between $p \mathrm{CO}_{2}$ level and $p \mathrm{CO}_{2}$ variability on chlorophyll $a$ content of $T$. oceanica was found.

POC and PON quotas of both species were elevated in the $\mathrm{OA}$ scenario in both the steady and fluctuating regimes, relative to present-day $p \mathrm{CO}_{2}$ levels (Table 2). However, no effects of the fluctuating regime on cellular POC and PON contents were detected in either species compared to the steady treatments. The only exception was that POC increased by $9 \%$ in the LCf treatment relative to the LCs treatment for T. weissflogii. Generally, elevated $p \mathrm{CO}_{2}$ and the fluctuating regime showed no effects on BSi quota of either species, besides a slight decrease in the $\mathrm{HCf}$ treatment relative to that of the HCs treatment for $T$. weissflogii.

The fluctuating regime increased the $\mathrm{POC}$ production rate of $T$. weissflogii at both ambient and elevated $p \mathrm{CO}_{2}$ levels, but had no effects on other elemental production rates of this species. By contrast, the fluctuating regime decreased all of the elemental production rates in the OA scenario for T. oceanica (Fig. 3). Significant interactions between $p \mathrm{CO}_{2}$ 

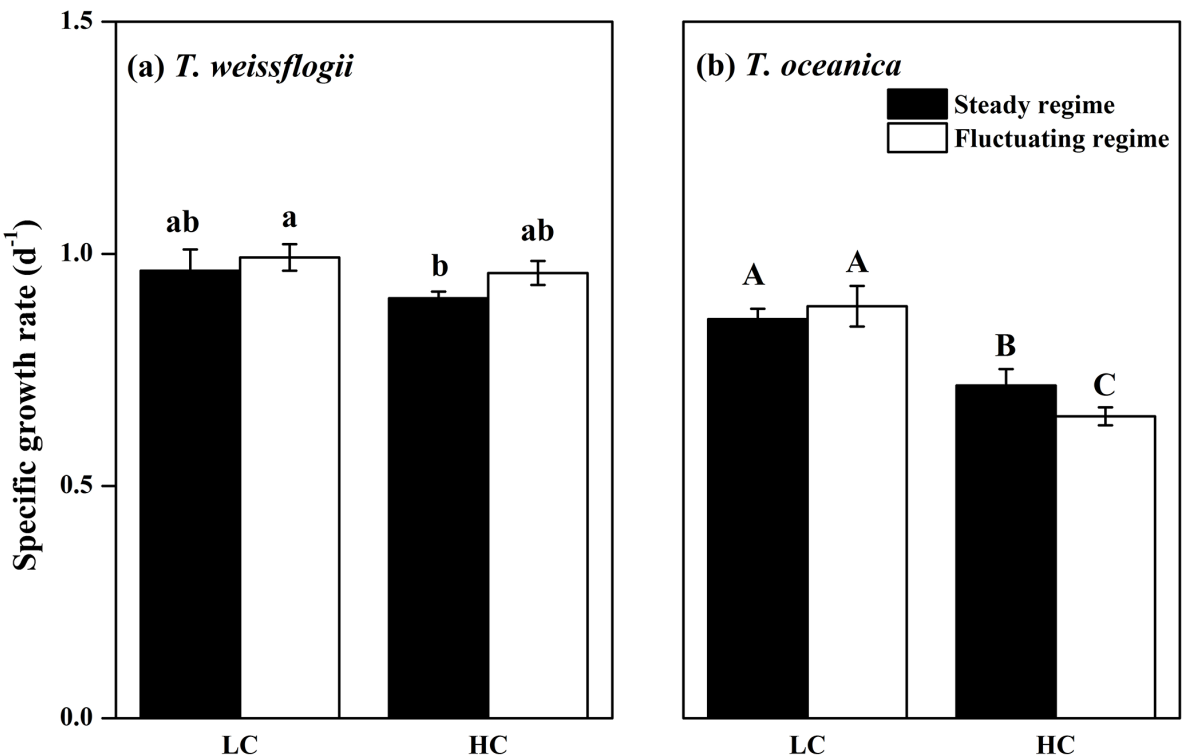

Figure 2. Specific growth rates of T. weissflogii (a) and T. oceanica (b) under steady (closed bars) and fluctuating (open bars) regimes of ambient (LC) and elevated ( $\mathrm{HC}) p \mathrm{CO}_{2}$ levels. Values are means $\pm \mathrm{SD}$ of triplicate cultures. The different letters indicate significant $(p<0.05)$ differences among treatments.

Table 2. Cell size, respiration to photosynthesis ratio ( $\mathrm{R}: \mathrm{P})$, cellular quotas of chlorophyll, particulate organic carbon (POC), particulate organic nitrogen $(\mathrm{PON})$, and biogenic silica $(\mathrm{BSi})$ and elemental ratios of $T$. weissflogii and $T$. oceanica under steady and fluctuating regimes of ambient (LC) and elevated (HC) $p \mathrm{CO}_{2}$ levels. Values are means $\pm \mathrm{SD}$ of triplicate cultures. The different superscripted letters (lowercase for $T$. weissflogii and uppercase for T. oceanica) indicate significant $(p<0.05)$ differences among treatments.

\begin{tabular}{|c|c|c|c|c|c|c|c|c|}
\hline & \multicolumn{4}{|c|}{ T. weissflogii } & \multicolumn{4}{|c|}{ T. oceanica } \\
\hline & LCs & LCf & $\mathrm{HCs}$ & $\mathrm{HCf}$ & LCs & LCf & $\mathrm{HCs}$ & $\mathrm{HCf}$ \\
\hline Cell size $(\mu \mathrm{m})$ & $12.17 \pm 0.05^{\mathrm{a}}$ & $12.17 \pm 0.05^{\mathrm{a}}$ & $12.20 \pm 0.04^{\mathrm{a}}$ & $12.18 \pm 0.04^{\mathrm{a}}$ & $5.58 \pm 0.01^{\mathrm{A}}$ & $5.65 \pm 0.03^{\mathrm{B}}$ & $5.71 \pm 0.02^{\mathrm{C}}$ & $5.63 \pm 0.02^{\mathrm{B}}$ \\
\hline Cellular quotas & & & & & & & & \\
\hline Chl $a\left(\mathrm{pg} \mathrm{cell}^{-1}\right)$ & $3.24 \pm 0.14^{\mathrm{a}}$ & $3.15 \pm 0.05^{\mathrm{a}}$ & $3.25 \pm 0.05^{\mathrm{a}}$ & $3.27 \pm 0.07^{\mathrm{a}}$ & $0.30 \pm 0.03^{\mathrm{A}}$ & $0.33 \pm 0.02^{\mathrm{AB}}$ & $0.38 \pm 0.06^{\mathrm{B}}$ & $0.29 \pm 0.02^{\mathrm{A}}$ \\
\hline POC ( $\left.\mathrm{pmol} \mathrm{cell}^{-1}\right)$ & $6.94 \pm 0.36^{\mathrm{a}}$ & $7.59 \pm 0.23^{b}$ & $10.28 \pm 0.29^{\mathrm{c}}$ & $10.28 \pm 0.28^{\mathrm{c}}$ & $1.49 \pm 0.12^{\mathrm{A}}$ & $1.68 \pm 0.20^{\mathrm{A}}$ & $2.38 \pm 0.17^{\mathrm{B}}$ & $2.20 \pm 0.07^{\mathrm{B}}$ \\
\hline PON (pmol cell ${ }^{-1}$ ) & $1.21 \pm 0.14^{\mathrm{a}}$ & $1.34 \pm 0.12^{\mathrm{a}}$ & $1.94 \pm 0.11^{\mathrm{b}}$ & $1.80 \pm 0.06^{\mathrm{b}}$ & $0.25 \pm 0.03^{A}$ & $0.29 \pm 0.01^{\mathrm{A}}$ & $0.49 \pm 0.03^{B}$ & $0.44 \pm 0.03^{\mathrm{B}}$ \\
\hline BSi (pmol cell ${ }^{-1}$ ) & $1.11 \pm 0.01^{\mathrm{ab}}$ & $1.06 \pm 0.04^{\mathrm{a}}$ & $1.19 \pm 0.10^{\mathrm{b}}$ & $1.04 \pm 0.04^{\mathrm{a}}$ & $0.35 \pm 0.03^{\mathrm{A}}$ & $0.34 \pm 0.03^{\mathrm{A}}$ & $0.32 \pm 0.02^{\mathrm{AB}}$ & $0.29 \pm 0.01^{\mathrm{B}}$ \\
\hline Ratios & & & & & & & & \\
\hline $\mathrm{C}: \mathrm{N}$ (pmol : pmol) & $5.78 \pm 0.40^{\mathrm{a}}$ & $5.68 \pm 0.32^{\mathrm{a}}$ & $5.30 \pm 0.20^{\mathrm{a}}$ & $5.72 \pm 0.24^{\mathrm{a}}$ & $6.10 \pm 0.60^{\mathrm{A}}$ & $5.87 \pm 0.70^{\mathrm{AB}}$ & $4.90 \pm 0.16^{\mathrm{B}}$ & $5.05 \pm 0.36^{\mathrm{B}}$ \\
\hline $\mathrm{Si}: \mathrm{C}$ (pmol : pmol) & $0.16 \pm 0.01^{\mathrm{a}}$ & $0.14 \pm 0.01^{b}$ & $0.12 \pm 0.01^{\mathrm{c}}$ & $0.10 \pm 0.01^{\mathrm{c}}$ & $0.24 \pm 0.02^{\mathrm{A}}$ & $0.20 \pm 0.02^{\mathrm{B}}$ & $0.14 \pm 0.01^{\mathrm{C}}$ & $0.13 \pm 0.01^{\mathrm{C}}$ \\
\hline $\begin{array}{l}\mathrm{R}: \mathrm{P}\left(\mathrm{fmol} \text { cell }{ }^{-1} \mathrm{~h}^{-1}:\right. \\
\left.\text { fmol cell }{ }^{-1} \mathrm{~h}^{-1}\right)\end{array}$ & $0.08 \pm 0.01^{\mathrm{a}}$ & $0.08 \pm 0.02^{\mathrm{a}}$ & $0.13 \pm 0.03^{b}$ & $0.14 \pm 0.03^{b}$ & $0.27 \pm 0.07^{\mathrm{A}}$ & $0.55 \pm 0.12^{\mathrm{B}}$ & $0.29 \pm 0.06^{\mathrm{A}}$ & $0.39 \pm 0.04^{\mathrm{A}}$ \\
\hline
\end{tabular}

level and $p \mathrm{CO}_{2}$ variability on elemental production rates of T. oceanica were found. Slight but significant decreases in the $\mathrm{Si}: \mathrm{C}$ ratio in the fluctuating regime compared to the steady regime were found at ambient $p \mathrm{CO}_{2}$ for both species (Table 2). The Si : C ratio of $T$. weissflogii was lower in the OA scenario, and $\mathrm{C}: \mathrm{N}$ ratios of $T$. weissflogii were not significant different among the four treatments. For T. oceanica, cells showed lower $\mathrm{C}: \mathrm{N}$ and $\mathrm{Si}: \mathrm{C}$ ratios at elevated $p \mathrm{CO}_{2}$ relative to cells grown at ambient $p \mathrm{CO}_{2}$.

\subsection{Chlorophyll $a$ fluorescence}

The effective photochemical quantum yields of both species varied little at different time points, ranging from $0.54 \pm 0.03$ to $0.61 \pm 0.03$ among treatments (Table 3). Fluctuating regimes scarcely influenced $\Phi_{\text {PSII }}$ of either species. The only exception was that $\Phi_{\text {PSII }}$ of HCf decreased by $8 \%$ relative to that of the HCs for T. weissflogii at $0.5 \mathrm{~h}$ after the onset of light. Elevated $p \mathrm{CO}_{2}$ decreased $\Phi_{\text {PSII }}$ by 3 and $2 \%$ for T. weissflogii at 6 and $11.5 \mathrm{~h}$ after the onset of light, respectively. $T$. oceanica cells under elevated $p \mathrm{CO}_{2}$ showed 5 and $7 \%$ lower $\Phi_{\text {PSII }}$ compared to those under ambient $p \mathrm{CO}_{2}$ at 6 and $11.5 \mathrm{~h}$ after the onset of light, respectively. NPQ under culture light intensity ranged from $0.06 \pm 0.01$ to $0.23 \pm 0.05$ at different time points. No detectable effects of the fluctuating regime on NPQ of either species were found, with the exceptions of HCf cells of $T$. weissflogii at $0.5 \mathrm{~h}$ after the on- 

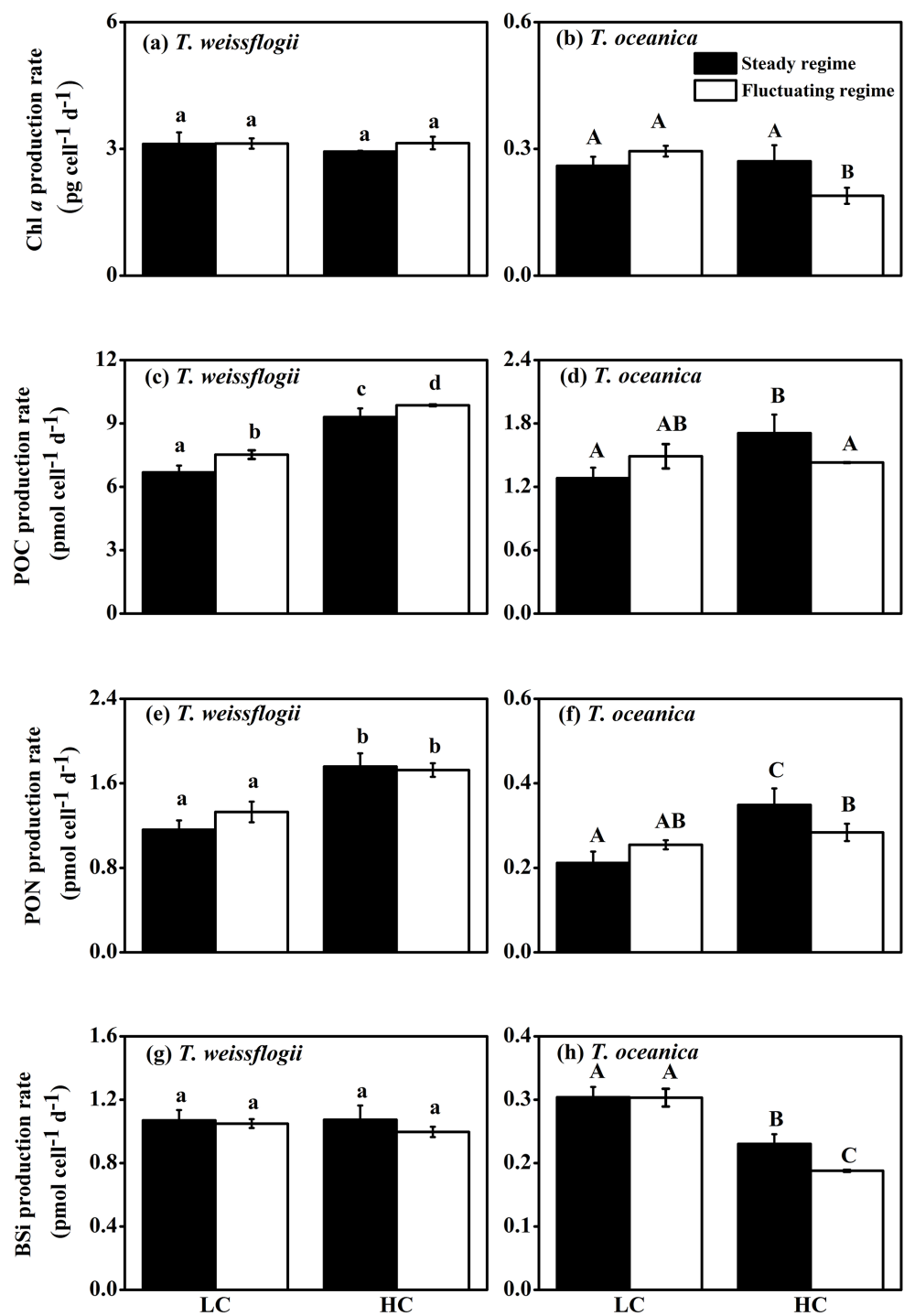

Figure 3. Production rates of chlorophyll $a(\mathbf{a}, \mathbf{b}), \mathrm{POC}(\mathbf{c}, \mathbf{d}), \mathrm{PON}(\mathbf{e}, \mathbf{f})$, and BSi $(\mathbf{g}, \mathbf{h})$ of $T$. weissflogii $(\mathbf{a}, \mathbf{c}, \mathbf{e}, \mathbf{g})$ and $T$. oceanica $(\mathbf{b}, \mathbf{d}$, $\mathbf{f}, \mathbf{h})$ under steady (closed bars) and fluctuating (open bars) regimes of ambient (LC) and elevated (HC) $p \mathrm{CO}_{2}$ levels. Values are means $\pm \mathrm{SD}$ of triplicate cultures. The different letters indicate significant $(p<0.05)$ differences among treatments.

set of light and LCf cells of $T$. oceanica $11.5 \mathrm{~h}$ after the onset of light. For steady regimes, elevated $p \mathrm{CO}_{2}$ showed no detectable effect on NPQ of both species at $0.5 \mathrm{~h}$ after the onset of light, while it increased NPQ of T. weissflogii by $37.5 \%$ and decreased it by $25 \%$ relative to values of LCs cells at 6 and $11.5 \mathrm{~h}$ after the onset of light, respectively. Values of NPQ of T. oceanica HCs cells were enhanced by $38.4 \%$ and decreased by $33.3 \%$ relative to values of LCs cells at 6 and $11.5 \mathrm{~h}$ after the onset of light, respectively.

\subsection{Photosynthetic oxygen evolution and dark respiration rates}

Chlorophyll-normalized net oxygen evolution rates of these two species ranged from $0.39 \pm 0.07$ to $0.55 \pm 0.07 \mu \mathrm{mol}$
$\mathrm{O}_{2} \mu \mathrm{g} \mathrm{Chl} a^{-1} \mathrm{~h}^{-1}$ at $6 \mathrm{~h}$ after the onset of light. Neither elevated $p \mathrm{CO}_{2}$ nor the fluctuating regime showed detectable effects on oxygen evolution rates per chlorophyll of T. weissflogii (Fig. 4a), while T. oceanica cells under the LCf treatment showed a $29 \%$ lower chlorophyll-normalized net oxygen evolution rate relative to the LCs cells (Fig. 4b). A significant interaction between $p \mathrm{CO}_{2}$ level and $p \mathrm{CO}_{2}$ variability on chlorophyll-normalized net oxygen evolution rate of $T$. oceanica was found. 

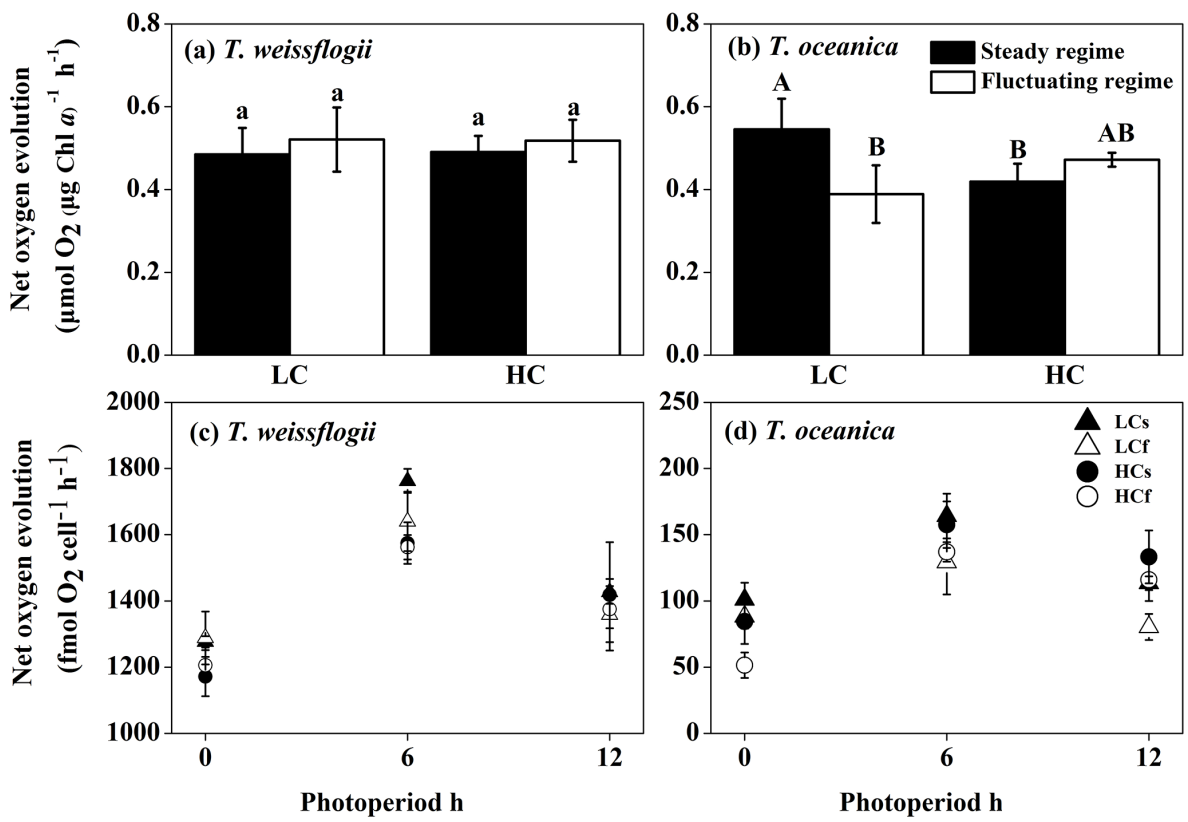

Figure 4. Chlorophyll-normalized net oxygen evolution rates determined at $6 \mathrm{~h}$ after the onset of light for T. weissflogii (a) and T. oceanica (b) under steady (closed bars) and fluctuating (open bars) regimes of ambient (LC) and elevated $(\mathrm{HC}) p \mathrm{CO}_{2}$ levels. Oxygen evolution rates per cell of $T$. weissflogii (c) and T. oceanica (d) of the four treatments determined $0.5,6$, and $11.5 \mathrm{~h}$ after the onset of light. Values are means \pm SD of triplicate cultures. The different letters indicate significant $(p<0.05)$ differences among treatments.

Table 3. Effective photochemical quantum yields ( $\left.\Phi_{\mathrm{PSII}}\right)$ and non-photochemical quenching (NPQ) determined $0.5,6$, and $11.5 \mathrm{~h}$ after the onset of light of $T$. weissflogii and T. oceanica under steady and fluctuating regimes of ambient (LC) and elevated $(\mathrm{HC}) p C \mathrm{O}_{2}$ levels. $\Phi_{\mathrm{PSII}}$ and NPQ were determined under actinic light intensity $\left(\sim 156 \mu \mathrm{mol}\right.$ photons $\left.\mathrm{m}^{-2} \mathrm{~s}^{-1}\right)$ similar to culture light level after $10 \mathrm{~min}$ of dark adaptation. Values are means \pm SD of triplicate cultures. The different superscripted letters (lowercase for $T$. weissflogii and uppercase for $T$. oceanica) indicate significant $(p<0.05)$ differences among treatments.

\begin{tabular}{|c|c|c|c|c|c|c|c|c|}
\hline \multirow[b]{2}{*}{ Time point } & \multicolumn{4}{|c|}{ T. weissflogii } & \multicolumn{4}{|c|}{ T. oceanica } \\
\hline & LCs & LCf & $\mathrm{HCs}$ & $\mathrm{HCf}$ & LCs & LCf & $\mathrm{HCs}$ & HCf \\
\hline \multicolumn{9}{|l|}{$\Phi_{\text {PSII }}$} \\
\hline $0.5 \mathrm{~h}$ & $0.61 \pm 0.01^{\mathrm{a}}$ & $0.61 \pm 0.01^{\mathrm{a}}$ & $0.59 \pm 0.01^{\mathrm{a}}$ & $0.54 \pm 0.03^{\mathrm{b}}$ & $0.57 \pm 0.03^{\mathrm{A}}$ & $0.58 \pm 0.01^{\mathrm{A}}$ & $0.59 \pm 0.06^{\mathrm{A}}$ & $0.61 \pm 0.03^{\mathrm{A}}$ \\
\hline $6 \mathrm{~h}$ & $0.60 \pm 0.01^{\mathrm{a}}$ & $0.60 \pm 0.01^{\mathrm{a}}$ & $0.58 \pm 0.01^{\mathrm{b}}$ & $0.59 \pm 0.01^{\mathrm{b}}$ & $0.57 \pm 0.01^{\mathrm{A}}$ & $0.57 \pm 0.01^{\mathrm{A}}$ & $0.54 \pm 0.01^{\mathrm{B}}$ & $0.56 \pm 0.01^{\mathrm{AB}}$ \\
\hline $11.5 \mathrm{~h}$ & $0.58 \pm 0.01^{\mathrm{a}}$ & $0.58 \pm 0.01^{\mathrm{a}}$ & $0.57 \pm 0.01^{\mathrm{b}}$ & $0.57 \pm 0.01^{\mathrm{ab}}$ & $0.61 \pm 0.03^{\mathrm{A}}$ & $0.60 \pm 0.03^{\mathrm{AB}}$ & $0.57 \pm 0.01^{\mathrm{B}}$ & $0.57 \pm 0.01^{\mathrm{AB}}$ \\
\hline \multicolumn{9}{|l|}{ NPQ } \\
\hline $0.5 \mathrm{~h}$ & $0.13 \pm 0.02^{\mathrm{a}}$ & $0.13 \pm 0.01^{\mathrm{a}}$ & $0.13 \pm 0.01^{\mathrm{a}}$ & $0.23 \pm 0.05^{\mathrm{b}}$ & $0.10 \pm 0.02^{\mathrm{A}}$ & $0.06 \pm 0.02^{\mathrm{A}}$ & $0.08 \pm 0.05^{\mathrm{A}}$ & $0.12 \pm 0.09^{\mathrm{A}}$ \\
\hline $6 \mathrm{~h}$ & $0.08 \pm 0.03^{\mathrm{a}}$ & $0.08 \pm 0.02^{\mathrm{ab}}$ & $0.11 \pm 0.01^{\mathrm{b}}$ & $0.09 \pm 0.01^{\mathrm{ab}}$ & $0.13 \pm 0.02^{\mathrm{A}}$ & $0.14 \pm 0.01^{\mathrm{A}}$ & $0.18 \pm 0.02^{\mathrm{B}}$ & $0.19 \pm 0.01^{\mathrm{B}}$ \\
\hline $11.5 \mathrm{~h}$ & $0.08 \pm 0.01^{\mathrm{a}}$ & $0.07 \pm 0.01^{\mathrm{a}}$ & $0.06 \pm 0.01^{\mathrm{b}}$ & $0.07 \pm 0.01^{\mathrm{ab}}$ & $0.09 \pm 0.02^{\mathrm{A}}$ & $0.06 \pm 0.01^{\mathrm{B}}$ & $0.06 \pm 0.01^{\mathrm{B}}$ & $0.07 \pm 0.01^{\mathrm{AB}}$ \\
\hline
\end{tabular}

Both species, regardless of treatment, showed a similar diurnal rhythm of photosynthetic oxygen evolution: oxygen evolution rates reached the highest values at $6 \mathrm{~h}$ after the onset of light (Fig. 4c, d). For T. weissflogii, effects of fluctuating $p \mathrm{CO}_{2}$ on net oxygen evolution per cell were only observed at $6 \mathrm{~h}$ after the onset of light for cells at the ambient $p \mathrm{CO}_{2}$ level, with $7 \%$ lower rates in the LCf treatment than in the LCs (Fig. 4c). These effects were more obvious for $T$. oceanica cells. T. oceanica cells in the steady regime under elevated $p \mathrm{CO}_{2}$ evolved oxygen at $65 \%$ higher cell-specific rates than those in the fluctuating regime at $0.5 \mathrm{~h}$ after the onset of light (Fig. 4d). At $11.5 \mathrm{~h}$ after the onset of light, LCs cells of $T$. oceanica showed $41 \%$ higher net oxygen evolution rates per cell than LCf cells. There were no differences in photosynthetic oxygen evolution rates between $\mathrm{HCs}$ and $\mathrm{HCf}$ cells $11.5 \mathrm{~h}$ after the onset of light.

Elevated $p \mathrm{CO}_{2}$ increased dark respiration of T. weissflogii by $57 \%$ compared to that at ambient $p \mathrm{CO}_{2}$ level, while the fluctuating regime had no detectable effect (Fig. 5a). In contrast, dark respiration rates of $T$. oceanica were stimulated by $60 \%$ for cells under the fluctuating regime compared to steady one at ambient $p \mathrm{CO}_{2}$ level (Fig. 5b), while no effects of the fluctuating regime at elevated $p \mathrm{CO}_{2}$ were observed. Dark respiration rates of $T$. oceanica were similar in 

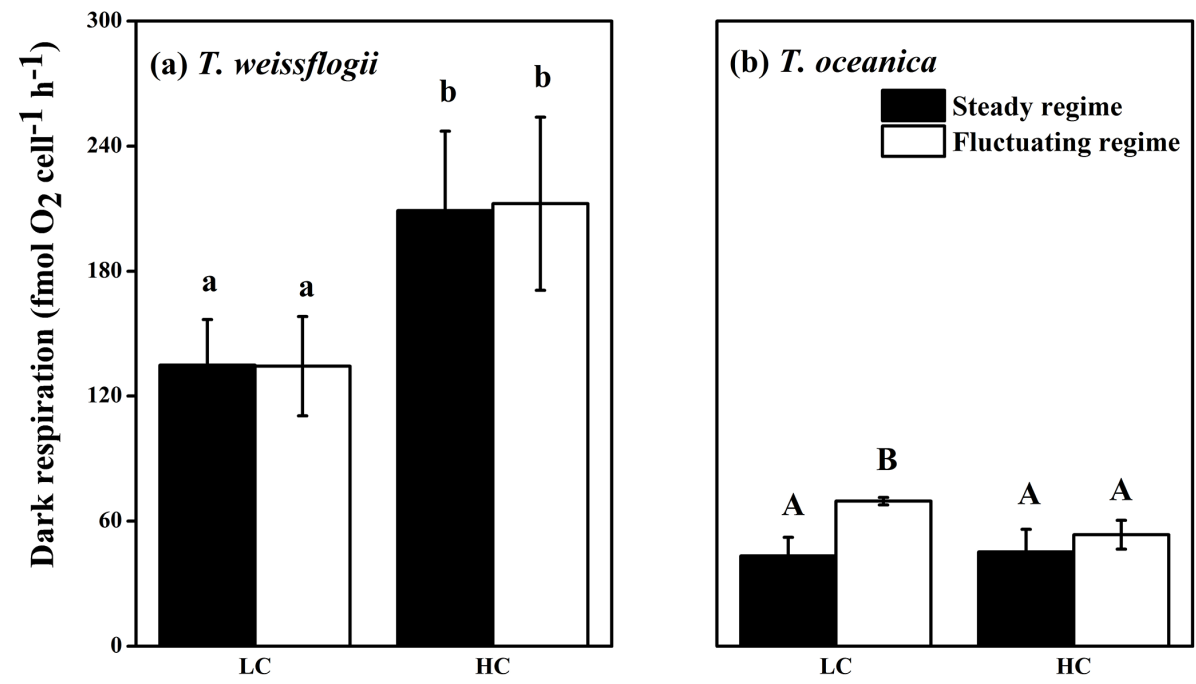

Figure 5. Dark respiration rates determined at $6 \mathrm{~h}$ after the onset of light for $T$. weissflogii (a) and T. oceanica (b) under steady (closed bars) and fluctuating (open bars) regimes of ambient (LC) and elevated (HC) $p \mathrm{CO}_{2}$ levels. Values are means $\pm \mathrm{SD}$ of triplicate cultures. The different letters indicate significant $(p<0.05)$ differences among treatments.

the steady regimes of ambient and elevated $p \mathrm{CO}_{2}$ levels. The respiration to net photosynthesis $(\mathrm{R}: \mathrm{P})$ ratios for $T$. weissflogii under elevated $p \mathrm{CO}_{2}$ was higher than at ambient $p \mathrm{CO}_{2}$ by $73 \%$, while no effects of the fluctuating regime were detected. R:P ratios for T. oceanica cells were higher by $104 \%$ in the fluctuating regime than for cells in the corresponding steady regime at ambient $p \mathrm{CO}_{2}$ level (Table 2).

\section{Discussion}

Both species were influenced by elevated $p \mathrm{CO}_{2}$ in several ways, while they responded differentially to the fluctuating regime. In general, for the coastal diatom T. weissflogii, the fluctuating $p \mathrm{CO}_{2}$ regime showed either positive (POC cellular quota and production rate) or no obvious effects on its physiological performance. In contrast, the oceanic diatom $T$. oceanica was significantly negatively affected by the diurnal variation of carbonate chemistry. The fluctuating regime reduced photosynthetic oxygen evolution rates and enhanced dark respiration rates under ambient $p \mathrm{CO}_{2}$ concentration, while in the OA scenario, the fluctuating regime depressed its growth rate, chlorophyll $a$ content, and elemental production rates (which were caused by decreased growth rates).

OA depressed the growth of $T$. oceanica, consistent with results of a previous study (King et al., 2015), which showed a similar decrease (19\%) to the present study (16\%). No detectable effects of OA on growth of T. weissflogii were found, as reported by previous studies (Burkhardt et al., 1999; Shi et al., 2009; Reinfelder, 2012; King et al., 2015; Passow and Laws, 2015; Taucher et al., 2015). However, the growth responses of diatoms have also been shown to be affected by interactions between OA and other abiotic factors. For in- stance, the energy saved from active inorganic carbon acquisition mechanisms due to increased availability of $\mathrm{CO}_{2}$ under OA conditions enhanced the growth of diatoms when daytime mean light level was lower than $22-36 \%$ of sea surface solar light intensity. However, growth under OA condition decreased when light exceeded $25-42 \%$ of incident irradiance (Gao et al., 2012). OA reduced the growth rate of $T$. weissflogii under light and temperature stress, but no effects of OA were detected in the absence of temperature stress (Passow and Laws, 2015). Consequently, it appears that effects of OA on phytoplankton species could be regionspecific, depending on the local interactions with other abiotic factors.

The silicified cell walls of diatoms act as mechanical protection to resist grazers (Hamm et al., 2003) and also have potential roles in photoprotection (Raven and Waite, 2004), as well as promotion of catalysis by extracellular carbonic anhydrase (Milligan and Morel 2002). The $\mathrm{Si}$ : C ratio of both species decreased under the elevated $p \mathrm{CO}_{2}$ condition, in accordance with results of Tatters et al. (2012) and Mejia et al. (2013). This decreased ratio indicates that the tested species may fix more carbon per silicon assimilated in the OA scenario than under the ambient $p \mathrm{CO}_{2}$ condition, thus having implications for changes in local and global carbon and silicon budgets. More carbon may be fixed per diatom cell without changes in silicon quota in the OA scenario, and thus the tested species may contribute more to primary production in the ecosystem, especially in Si-limited waters, in the future oceans. However, diatom silicification is under a complex set of controls. For instance, limitation by other nutrients, such as iron (Hutchins and Bruland, 1998) and nitrogen (Flynn and Martin-Jézéquel, 2000), may act to increase $\mathrm{Si}$ quotas and $\mathrm{Si}: \mathrm{C}$ ratio. 
Bicarbonate utilization has been suggested to be a general characteristic of marine diatoms, through direct transport or conversion by extracellular carbonic anhydrase (eCA), while the fraction of direct bicarbonate transport and eCA expression varies among species (Martin and Tortell, 2008). Pathways that can utilize $\mathrm{HCO}_{3}^{-}$and provide $\mathrm{CO}_{2}$ for RuBisCo through $\mathrm{C}_{4}$ (Reinfelder et al., 2000) or $\mathrm{C}_{3}-\mathrm{C}_{4}$ intermediate photosynthesis (Roberts et al., 2007) have been suggested for T. weissflogii. This species takes up both $\mathrm{CO}_{2}$ and $\mathrm{HCO}_{3}^{-}$at a similar rate and has the ability to adjust uptake rates to cope with a wide range of inorganic carbon supplies (Burkhardt et al., 2001). Moreover, T. weissflogii has a markedly higher fraction of direct bicarbonate transport and apparent eCA activity than T. oceanica (Martin and Tortell, 2008), which may facilitate their inorganic carbon transport and uptake. In this study, T. oceanica showed significantly lower oxygen evolution rates in the LCf treatment than in the LCs treatment at $11.5 \mathrm{~h}$ after the onset of light, when the highest $\mathrm{pH}$ and lowest $\mathrm{CO}_{2}$ was reached. In contrast, no effects of the fluctuating regime on oxygen evolution rates of $T$. weissflogii were found at this time point. Thus, T. weissflogii cells were more tolerant of the high $\mathrm{pH}$ and low $\mathrm{CO}_{2}$ period under fluctuating carbonate chemistry than $T$. oceanica.

Under the fluctuating regime, T. oceanica showed higher respiration rates in the current scenario than under the corresponding steady regime. As with the successful compromise between iron requirements and capacity to acclimate to dynamic light regimes in T. oceanica cells (Strzepek and Harrison 2004), this oceanic diatom may also have evolved to acclimate to fluctuating carbonate chemistry in a different way compared with the coastal diatom. The higher respiration rate under the fluctuating regime in the current scenario may imply that this species needs more energy for maintaining its intracellular acid-base balance under dynamic extracellular $\mathrm{pH}$ conditions, as dark respiration provides energy for growth and metabolic processes (Raven and Beardall, 2005). Diatoms were shown to exhibit circadian variations in photosynthesis and respiration (Weger et al., 1989; Chen and Gao, 2004). Thus, dark respiration might show different pattern at other time points, as photosynthetic oxygen evolution did. $T$. oceanica cells showed significantly higher $\mathrm{R}: \mathrm{P}$ ratios than T. weissflogii, especially in the fluctuating regime at ambient $p \mathrm{CO}_{2}$, and the ratios were within previously reported ranges in diatoms (Geider and Osborne, 1989). The higher R : P ratio indicated greater proportions of photosynthetic fixed carbon and associated energy were used for growth, biosynthesis, and maintaining intracellular homeostasis in the oceanic species. Moreover, the fluctuating regime reduced the production rate of organic matter by $T$. oceanica at elevated $p \mathrm{CO}_{2}$. Depressed biomass build-up has also been found under dynamic light regimes (Wagner et al., 2006; Shatwell et al., 2012; Hoppe et al., 2015). Together with our results, this may imply that organisms that are sensitive to fluctuating abiotic factors maintain intracellular homeostasis under dynamic environments of light or $p \mathrm{CO}_{2}$ at the expense of reduced biomass production.

Either positive (POC production rate) or no obvious effects of the fluctuating regime on biomass production were found in the coastal species T. weissflogii. Coastal calcifying organisms have shown the ability to achieve homeostasis within critical tissues to facilitate calcification under dynamic $\mathrm{pH} / p \mathrm{CO}_{2}$ condition, and this was suggested to be associated with diurnal and seasonal $\mathrm{pH}$ fluctuations in coastal waters (Hendriks et al., 2015). Thus, some organisms could take advantage of the fluctuating carbonate system regime to mitigate the negative effects of ocean acidification on physiological performance. For instance, growth and calcification of corals can benefit from oscillatory $p \mathrm{CO}_{2}$ (Dufault et al., 2012; Comeau et al., 2014). Organisms like T. weissflogii whose physiological performance were enhanced or unaltered under dynamic carbonate chemistry conditions thus could be at a distinct advantage in competing with species that showed negative responses to this condition (such as T. oceanica in the present study). The differential responses of the tested two species to the fluctuating carbonate chemistry may be partially attributed to the differences in cell size. The differences in carbonate chemistry and $\mathrm{pH}$ between the bulk medium and the exterior surface of marine organisms increase as cell size increases (Flynn et al., 2012). Thus, the larger species, T. weissflogii, theoretically possesses higher adaptability to cope with the varied carbonate chemistry and $\mathrm{pH}$, as it is frequently encountered in the natural coastal waters and their exterior surfaces.

Schaum et al. (2016) found that short-term plastic responses to high $p \mathrm{CO}_{2}$ disappeared in a green microalgae after extended experimental evolution at high $p \mathrm{CO}_{2}$, particularly in fluctuating $p \mathrm{CO}_{2}$ treatments. Whether a similar phenomenon may be operative in other algal groups, such as diatoms following exposures to high, fluctuating $p \mathrm{CO}_{2}$ that are longer than those we employed, is currently unknown. However, it is notable that growth rates and competitive abilities of diatoms of a natural community showed little change following 1 year of conditioning at two $p \mathrm{CO}_{2}$ levels and three temperatures, relative to the results of a short-term experiment conducted on the original collected community (Tatters et al., 2013). Regardless of the responses of cell physiology to different timescales of changes in $p \mathrm{CO}_{2}$ concentrations, it is a significant observation that the fluctuating regime reduced the production rate of organic matter in $T$. oceanica at elevated $p \mathrm{CO}_{2}$ (which were caused by decreased growth rates).

The effect of the fluctuating regime on T. oceanica was different in the current and OA scenarios. Under elevated rather than current $p \mathrm{CO}_{2}$ conditions, fluctuating carbonate chemistry decreased pigment content and the production rate of organic matter. Although elevated $\mathrm{CO}_{2}$ mitigated the negative effects of the fluctuating regime on photosynthetic oxygen evolution rates of $T$. oceanica cells under ambient $p \mathrm{CO}_{2}$ condition, the effect of the fluctuating regime under elevated 
$p \mathrm{CO}_{2}$ tended to be negative, resulting in a decreased growth rate compared to the steady regime. The diurnal $\mathrm{pH}$ variation range $(\sim 0.5$ units) used in the present study is realistic for coastal ecosystems, like upwelling regions (Hofmann et al., 2011), kelp forests (Cornwall et al., 2013), coastal coral reefs (Wang et al., 2014), and tide pools (Morris and Taylor, 1983). In contrast, $\mathrm{pH}$ in the open ocean is relatively stable, with a variation range of only $\sim 0.024$ over a month (Hofmann et al., 2011). The same amplitude of $\mathrm{pH}$ variation was set in the current and elevated $p \mathrm{CO}_{2}$ scenarios in the present study. Buffering capacity will decrease as the dissolved inorganic carbon in both coastal and oceanic seawater increases under projected elevated $p \mathrm{CO}_{2}$ conditions (Egleston et al., 2010; Cai et al., 2011; Denman et al., 2011; Wang et al., 2013). For instance, the Revelle factor increased from $10.6 \pm 0.2$ to $15.0 \pm 0.2$ (a higher Revelle factor indicates a lower buffer capacity) when $p \mathrm{CO}_{2}$ increased from the ambient to the elevated level in the present study. The increase amplitude of $\mathrm{pH}$ variation in coastal water will be more apparent than in oceanic water under an OA scenario, due to high biomass and sufficient nutrients. With a larger diurnal $\mathrm{pH}$ variation range in the future ocean, T. oceanica would be affected more than observed in the present study. Thus, based on our results, the competitive disadvantage for organisms like T. oceanica under fluctuating carbonate chemistry conditions would be amplified in the OA scenario.

Given the decreased growth and elemental production rates of $T$. oceanica under fluctuating seawater carbonate chemistry in the OA scenario, and its limited ability to dissipate excess excitation energy through NPQ under high light (Strzepek and Harrison, 2004), this species is unlikely to be able to acclimate to coastal habitats, where major fluctuations in light and carbonate chemistry will exist, in the future oceans. In contrast, T. weissflogii appears to be insensitive to, or even benefit from, fluctuating carbonate chemistry. This striking contrast of physiological traits in coastal and oceanic diatoms suggests that the ability to cope with fluctuating carbonate chemistry may play a role in influencing the geographic distributions of species under OA conditions. It is possible that this ability, together with the abilities to cope with nutrient (Irwin et al., 2006), light (Lavaud et al., 2007; Lavaud and Lepetit, 2013; Laviale et al., 2015), and predation pressure (Irigoien et al., 2005), will determine the spatial distribution patterns of species in the future oceans. However, phytoplankton are known to exhibit species-specific response to environmental factors (including OA, fluctuating carbonate chemistry, etc.), and thus more studies on the responses of phytoplankton at the species and community levels are needed to predict such broad biogeographic trends.

\section{Data availability}

Data in the present study are available at https://issues. pangaea.de/browse/PDI-13534.
Acknowledgements. We would like to thank the two anonymous reviewers and Christine Klaas for their insightful comments on the manuscript. This study was supported by the State Oceanic Administration (SOA, GASI-03-01-02-04), the National Natural Science Foundation (41430967, 41120164007, 41206091), the Joint Project of NSFC and Shandong Province (Grant no. U1406403), the Strategic Priority Research Program of Chinese Academy of Sciences (grant no. XDA11020302), the Fundamental Research Funds for the Central Universities (20720150076), and the US National Science Foundation through grant OCE 1538525 to Feixue Fu and David A. Hutchins. We thank John Beardall for his suggestions for experimental design and Dalin Shi for providing Thalassiosira weissflogii. We are grateful to Hangbin Miao and Dong Yan for their help with the experiments.

Edited by: C. Klaas

Reviewed by: two anonymous referees

\section{References}

Britton, D., Cornwall, C. E., Revill, A. T., Hurd, C. L., and Johnson, C. R.: Ocean acidification reverses the positive effects of seawater $\mathrm{pH}$ fluctuations on growth and photosynthesis of the habitat-forming kelp, Ecklonia radiata, Sci. Rep., 6, 26036, doi:10.1038/srep26036, 2016.

Brzezinski, M. A. and Nelson, D. M.: The annual silica cycle in the Sargasso Sea near Bermuda, Deep-Sea Res. Pt I, 42, 1215-1237, 1995.

Burkhardt, S., Zondervan, I., and Riebesell, U.: Effect of $\mathrm{CO}_{2}$ concentration on $\mathrm{C}: \mathrm{N}: \mathrm{P}$ ratio in marine phytoplankton: A species comparison, Limnol. Oceanogr., 44, 683-690, 1999.

Burkhardt, S., Amoroso, G., Riebesell, U., and Sültemeyer, D.: $\mathrm{CO}_{2}$ and $\mathrm{HCO}_{3}^{-}$uptake in marine diatoms acclimated to different $\mathrm{CO}_{2}$ concentrations, Limnol. Oceanogr., 46, 1378-1391, 2001.

Cai, W.-J., Hu, X., Huang, W.-J., Murrell, M. C., Lehrter, J. C., Lohrenz, S. E., Chou, W.-C., Zhai, W., Hollibaugh, J. T., and Wang, Y.: Acidification of subsurface coastal waters enhanced by eutrophication, Nat. Geosci., 4, 766-770, 2011.

Capone, D. G. and Hutchins, D. A.: Microbial biogeochemistry of coastal upwelling regimes in a changing ocean, Nat. Geosci., 6, 711-717, 2013.

Chen, X. and Gao, K.: Characterization of diurnal photosynthetic rhythms in the marine diatom Skeletonema costatum grown in synchronous culture under ambient and elevated $\mathrm{CO}_{2}$, Funct. Plant. Biol., 31, 399-404, 2004.

Ciais, P., Sabine, C., Bala, G., Bopp, L., Brovkin, V., Canadell, J., Chhabra, A., DeFries, R., Galloway, J., and Heimann, M.: Carbon and other biogeochemical cycles, in: Climate change 2013: the physical science basis, Contribution of Working Group I to the Fifth Assessment Report of the Intergovernmental Panel on Climate Change, Cambridge University Press, 465-570, 2014.

Comeau, S., Edmunds, P. J., Spindel, N. B., and Carpenter, R. C.: Diel $p \mathrm{CO}_{2}$ oscillations modulate the response of the coral Acropora hyacinthus to ocean acidification, Mar. Ecol. Prog. Ser., 501, 99-111, 2014.

Cornwall, C. E., Hepburn, C. D., McGraw, C. M., Currie, K. I., Pilditch, C. A., Hunter, K. A., Boyd, P. W., and Hurd, C. L.: Diurnal fluctuations in seawater $\mathrm{pH}$ influence the response of a cal- 
cifying macroalga to ocean acidification, P. Roy. Soc. Lond. B, 280, 20132201, doi:10.1098/rspb.2013.2201, 2013.

Dai, M., Lu, Z., Zhai, W., Chen, B., Cao, Z., Zhou, K., Cai, W. J., and Chenc, C. T. A.: Diurnal variations of surface seawater $p \mathrm{CO}_{2}$ in contrasting coastal environments, Limnol. Oceanogr., 54, 735-745, 2009.

Denman, K., Christian, J. R., Steiner, N., Pörtner, H.-O., and Nojiri, Y.: Potential impacts of future ocean acidification on marine ecosystems and fisheries: current knowledge and recommendations for future research, ICES J. Mar. Sci., 68, 1019-1029, 2011.

Dixon, R. L.: Behavioral responses of common juvenile estuarine fishes to diel-cycling hypoxia and corresponding $\mathrm{pH}$ fluctuations: a comparative approach, Ph.D. thesis, University of Delaware, USA, 2014.

Doney, S. C.: The growing human footprint on coastal and openocean biogeochemistry, Science, 328, 1512-1516, 2010.

Drupp, P., De Carlo, E. H., Mackenzie, F. T., Bienfang, P., and Sabine, C. L.: Nutrient inputs, phytoplankton response, and $\mathrm{CO}_{2}$ variations in a semi-enclosed subtropical embayment, Kaneohe Bay, Hawaii, Aquat. Geochem., 17, 473-498, 2011.

Duarte, C. M., Hendriks, I. E., Moore, T. S., Olsen, Y. S., Steckbauer, A., Ramajo, L., Carstensen, J., Trotter, J. A., and McCulloch, M.: Is ocean acidification an open-ocean syndrome?, Understanding anthropogenic impacts on seawater $\mathrm{pH}$, Estuar. Coast., 36, 221-236, 2013.

Dufault, A. M., Cumbo, V. R., Fan, T.-Y., and Edmunds, P. J.: Effects of diurnally oscillating $p \mathrm{CO}_{2}$ on the calcification and survival of coral recruits, P. Roy. Soc. Lond. B, 279, 2951-2958, 2012.

Egleston, E. S., Sabine, C. L., and Morel, F. M.: Revelle revisited: Buffer factors that quantify the response of ocean chemistry to changes in DIC and alkalinity, Global Biogeochem. Cy., 24, GB1002, doi:10.1029/2008GB003407, 2010.

Feely, R. A., Sabine, C. L., Hernandez-Ayon, J. M., Ianson, D., and Hales, B.: Evidence for upwelling of corrosive "acidified" water onto the continental shelf, Science, 320, 1490-1492, 2008.

Flynn, K. J. and Martin-Jézéquel, V.: Modelling Si-N-limited growth of diatoms, J. Plankton Res., 22, 447-472, 2000.

Flynn, K. J., Blackford, J. C., Baird, M. E., Raven, J. A., Clark, D. R., Beardall, J., Brownlee, C., Fabian, H., and Wheeler, G. L.: Changes in $\mathrm{pH}$ at the exterior surface of plankton with ocean acidification, Nature Climate Change, 2, 510-513, 2012.

Frieder, C. A., Gonzalez, J. P., Bockmon, E. E., Navarro, M. O., and Levin, L. A.: Can variable $\mathrm{pH}$ and low oxygen moderate ocean acidification outcomes for mussel larvae?, Glob. Change Biol., 20, 754-764, 2014.

Gao, K., Aruga, Y., Asada, K., Ishihara, T., Akano, T., and Kiyohara, M.: Calcification in the articulated coralline alga Corallina pilulifera, with special reference to the effect of elevated $\mathrm{CO}_{2}$ concentration, Mar. Biol., 117, 129-132, 1993.

Gao, K., Xu, J., Gao, G., Li, Y., Hutchins, D. A., Huang, B., Wang, L., Zheng, Y., Jin, P., and Cai, X.: Rising $\mathrm{CO}_{2}$ and increased light exposure synergistically reduce marine primary productivity, $\mathrm{Na}$ ture Climate Change, 2, 519-523, 2012.

Gattuso, J.-P., Frankignoulle, M., and Wollast, R.: Carbon and carbonate metabolism in coastal aquatic ecosystems, Annu. Rev. Ecol. Syst., 29, 405-434, 1998.

Gattuso, J.-P., Magnan, A., Billé, R., Cheung, W., Howes, E., Joos, F., Allemand, D., Bopp, L., Cooley, S., and Eakin, C.:
Contrasting futures for ocean and society from different anthropogenic $\mathrm{CO}_{2}$ emissions scenarios, Science, 349, aac4722, doi:10.1126/science.aac4722, 2015.

Geider, R. J. and Osborne, B. A.: Respiration and microalgal growth: a review of the quantitative relationship between dark respiration and growth, New Phytol., 112, 327-341, 1989.

Genty, B., Briantais, J.-M., and Baker, N. R.: The relationship between the quantum yield of photosynthetic electron transport and quenching of chlorophyll fluorescence, BBA Gen. Subjects, 990, 87-92, 1989.

Glibert, P. and Ray, R.: Different patterns of growth and nitrogen uptake in two clones of marine Synechococcus spp., Mar. Biol., 107, 273-280, 1990.

Hamm, C. E., Merkel, R., Springer, O., Jurkojc, P., Maier, C., Prechtel, K., and Smetacek, V.: Architecture and material properties of diatom shells provide effective mechanical protection, Nature, 421, 841-843, 2003.

Hendriks, I. E., Duarte, C. M., Olsen, Y. S., Steckbauer, A., Ramajo, L., Moore, T. S., Trotter, J. A., and McCulloch, M.: Biological mechanisms supporting adaptation to ocean acidification in coastal ecosystems, Estuar. Coast. Shelf S., 152, A1-A8, doi:10.1016/j.ecss.2014.07.019, 2015.

Hofmann, G. E., Smith, J. E., Johnson, K. S., Send, U., Levin, L. A., Micheli, F., Paytan, A., Price, N. N., Peterson, B., and Takeshita, Y.: High-frequency dynamics of ocean pH: a multi-ecosystem comparison, PloS One, 6, e28983, doi:10.1371/journal.pone.0028983, 2011.

Hoppe, C. J., Holtz, L. M., Trimborn, S., and Rost, B.: Ocean acidification decreases the light-use efficiency in an Antarctic diatom under dynamic but not constant light, New Phytol., 207, 159$171,2015$.

Howes, E. L., Joos, F., Eakin, M., and Gattuso, J.: An updated synthesis of the observed and projected impacts of climate change on the chemical, physical and biological processes in the oceans, Front. Mar. Sci., 2, 36, doi:10.3389/fmars.2015.00036, 2015

Hurd, C. L., Cornwall, C. E., Currie, K., Hepburn, C. D., McGraw, C. M., Hunter, K. A., and Boyd, P. W.: Metabolically induced $\mathrm{pH}$ fluctuations by some coastal calcifiers exceed projected 22nd century ocean acidification: a mechanism for differential susceptibility?, Glob. Change Biol., 17, 3254-3262, 2011.

Hutchins, D. A. and Bruland, K. W.: Iron-limited diatom growth and $\mathrm{Si}$ : $\mathrm{N}$ uptake ratios in a coastal upwelling regime, Nature, 393, 561-564, 1998.

Irigoien, X., Flynn, K., and Harris, R.: Phytoplankton blooms: a "loophole" in microzooplankton grazing impact?, J. Plankton Res., 27, 313-321, 2005.

Irwin, A. J., Finkel, Z. V., Schofield, O. M. E., and Falkowski, P. G.: Scaling-up from nutrient physiology to the size-structure of phytoplankton communities, J. Plankton Res., 28, 459-471, 2006.

Jiang, Z.-P., Huang Jr., C., Dai, M., Kao, S. J., Hydes, D. J., Chou, W.-C., and Jan, S.: Short-term dynamics of oxygen and carbon in productive nearshore shallow seawater systems off Taiwan: Observations and modeling, Limnol. Oceanogr., 56, 1832-1849, 2011.

Johnson, M. D., Moriarty, V. W., and Carpenter, R. C.: Acclimatization of the crustose coralline alga Porolithon onkodes to variable $p \mathrm{CO}_{2}$, PloS One, 9, e87678, doi:10.1371/journal.pone.0087678, 2014. 
Keppel, A. G., Breitburg, D. L., Wikfors, G. H., Burrell, R. B., and Clark, V. M.: Effects of co-varying diel-cycling hypoxia and $\mathrm{pH}$ on disease susceptibility in the eastern oyster, Crassostrea virginica, Mar. Ecol. Prog. Ser., 538, 169-183, 2015.

King, A. L., Jenkins, B. D., Wallace, J. R., Liu, Y., Wikfors, G. H., Milke, L. M., and Meseck, S. L.: Effects of $\mathrm{CO}_{2}$ on growth rate, $\mathrm{C}: \mathrm{N}: \mathrm{P}$, and fatty acid composition of seven marine phytoplankton species, Mar. Ecol. Prog. Ser., 537, 59-69, 2015.

Lavaud, J. and Lepetit, B.: An explanation for the inter-species variability of the photoprotective non-photochemical chlorophyll fluorescence quenching in diatoms, BBA Bioenergetics, 1827, 294$302,2013$.

Lavaud, J., Strzepek, R. F., and Kroth, P. G.: Photoprotection capacity differs among diatoms: Possible consequences on the spatial distribution of diatoms related to fluctuations in the underwater light climate, Limnol. Oceanogr., 52, 1188-1194, 2007.

Laviale, M., Barnett, A., Ezequiel, J., Lepetit, B., Frankenbach, S., Méléder, V., Serôdio, J., and Lavaud, J.: Response of intertidal benthic microalgal biofilms to a coupled light-temperature stress: evidence for latitudinal adaptation along the Atlantic coast of Southern Europe, Environ. Microbiol., 17, 3662-3677, 2015.

Li, G., Gao, K., and Gao, G.: Differential impacts of solar UV radiation on photosynthetic carbon fixation from the coastal to offshore surface waters in the South China Sea, Photochem. Photobiol., 87, 329-334, 2011.

Liu, S.-W. and Qiu, B.-S.: Different responses of photosynthesis and flow cytometric signals to iron limitation and nitrogen source in coastal and oceanic Synechococcus strains (Cyanophyceae), Mar. Biol., 159, 519-532, 2012.

Martin, C. L. and Tortell, P. D.: Bicarbonate transport and extracellular carbonic anhydrase in marine diatoms, Physiol. Plantarum, 133, 106-116, 2008.

Mejia, L. M., Isensee, K., Méndez-Vicente, A., Pisonero, J., Shimizu, N., González, C., Monteleone, B., and Stoll, H.: B content and $\mathrm{Si}: \mathrm{C}$ ratios from cultured diatoms (Thalassiosira pseudonana and Thalassiosira weissflogii): Relationship to seawater $\mathrm{pH}$ and diatom carbon acquisition, Geochim. Cosmochim. Ac., 123, 322-337, 2013.

Milligan, A. J. and Morel, F. M.: A proton buffering role for silica in diatoms, Science, 297, 1848-1850, 2002.

Morris, S. and Taylor, A. C.: Diurnal and seasonal variation in physico-chemical conditions within intertidal rock pools, Estuar. Coast. Shelf S., 17, 339-355, 1983.

Noisette, F., Egilsdottir, H., Davoult, D., and Martin, S.: Physiological responses of three temperate coralline algae from contrasting habitats to near-future ocean acidification, J. Exp. Mar. Biol. Ecol., 448, 179-187, 2013.

Onitsuka, T., Kimura, R., Ono, T., Takami, H., and Nojiri, Y.: Effects of ocean acidification on the early developmental stages of the horned turban, Turbo cornutus, Mar. Biol., 161, 1127-1138, 2014.

Orr, J. C., Fabry, V. J., Aumont, O., Bopp, L., Doney, S. C., Feely, R. A., Gnanadesikan, A., Gruber, N., Ishida, A., and Joos, F.: Anthropogenic ocean acidification over the twenty-first century and its impact on calcifying organisms, Nature, 437, 681-686, 2005.

Passow, U. and Laws, E. A.: Ocean acidification as one of multiple stressors: growth response of Thalassiosira weissflogii (diatom) under temperature and light stress, Mar. Ecol. Prog. Ser., 541, 75-90, 2015.

Raven, J. and Waite, A.: The evolution of silicification in diatoms: inescapable sinking and sinking as escape?, New Phytol., 162, 45-61, 2004.

Raven, J. A. and Beardall, J.: Respiration in aquatic photolithotrophs, in: Respiration in aquatic ecosystems, edited by: del Giorgio, P. A. and le B. Williams, P. J., Oxford University Press, New York, USA, 36-46, 2005.

Reinfelder, J. R., Kraepiel, A. M., and Morel, F. M.: Unicellular C 4 photosynthesis in a marine diatom, Nature, 407, 996-999, 2000.

Reinfelder, J. R.: Carbon dioxide regulation of nitrogen and phosphorus in four species of marine phytoplankton, Mar. Ecol. Prog. Ser., 466, 57-67, 2012.

Ritchie, R. J.: Consistent sets of spectrophotometric chlorophyll equations for acetone, methanol and ethanol solvents, Photosynth. Res., 89, 27-41, 2006.

Roberts, K., Granum, E., Leegood, R. C., and Raven, J. A.: Carbon acquisition by diatoms, Photosynth. Res., 93, 79-88, 2007.

Sabine, C. L., Feely, R. A., Gruber, N., Key, R. M., Lee, K., Bullister, J. L., Wanninkhof, R., Wong, C., Wallace, D. W., and Tilbrook, B.: The oceanic sink for anthropogenic $\mathrm{CO}_{2}$, Science, 305, 367-371, 2004.

Schaum, C.-E., Rost, B., and Collins, S.: Environmental stability affects phenotypic evolution in a globally distributed marine picoplankton, ISME J., 10, 75-84, 2015.

Shatwell, T., Nicklisch, A., and Köhler, J.: Temperature and photoperiod effects on phytoplankton growing under simulated mixed layer light fluctuations, Limnol. Oceanogr., 57, 541-553, 2012.

Shi, D., Xu, Y., and Morel, F. M. M.: Effects of the $\mathrm{pH} / p \mathrm{CO}_{2}$ control method on medium chemistry and phytoplankton growth, Biogeosciences, 6, 1199-1207, doi:10.5194/bg-6-1199-2009, 2009.

Strzepek, R. F. and Harrison, P. J.: Photosynthetic architecture differs in coastal and oceanic diatoms, Nature, 431, 689-692, 2004.

Sunda, W. G., Price, N. M., and Morel, F. M.: Trace metal ion buffers and their use in culture studies, in: Algal culturing techniques, Elsevier Academic Press, 35-63, 2005.

Tatters, A. O., Fu, F.-X., and Hutchins, D. A.: High $\mathrm{CO}_{2}$ and silicate limitation synergistically increase the toxicity of Pseudo-nitzschia fraudulenta, PloS One, 7, e32116, doi:10.1371/journal.pone.0032116, 2012.

Tatters, A. O., Roleda, M. Y., Schnetzer, A., Fu, F., Hurd, C. L., Boyd, P. W., Caron, D. A., Lie, A. A., Hoffmann, L. J., and Hutchins, D. A.: Short-and long-term conditioning of a temperate marine diatom community to acidification and warming, Philos. T. Roy. Soc. B, 368, 20120437, doi:10.1098/rstb.2012.0437, 2013.

Taucher, J., Jones, J., James, A., Brzezinski, M. A., Carlson, C. A., Riebesell, U., and Passow, U.: Combined effects of $\mathrm{CO}_{2}$ and temperature on carbon uptake and partitioning by the marine diatoms Thalassiosira weissflogii and Dactyliosolen fragilissimus, Limnol. Oceanogr., 60, 901-919, 2015.

Wagner, H., Jakob, T., and Wilhelm, C.: Balancing the energy flow from captured light to biomass under fluctuating light conditions, New Phytol., 169, 95-108, 2006.

Waldbusser, G. G. and Salisbury, J. E.: Ocean acidification in the coastal zone from an organism's perspective: multiple system pa- 
rameters, frequency domains, and habitats, Annu. Rev. Mar. Sci., 6, 221-247, 2014.

Wang, G., Jing, W., Wang, S., Xu, Y., Wang, Z., Zhang, Z., Li, Q., and Dai, M.: Coastal acidification induced by tidal-driven submarine groundwater discharge in a coastal coral reef system, Environ. Sci. Technol., 48, 13069-13075, 2014.
Wang, Z. A., Wanninkhof, R., Cai, W.-J., Byrne, R. H., Hu, X., Peng, T.-H., and Huang, W.-J.: The marine inorganic carbon system along the Gulf of Mexico and Atlantic coasts of the United States: Insights from a transregional coastal carbon study, Limnol. Oceanogr., 58, 325-342, 2013.

Weger, H. G., Herzig, R., Falkowski, P. G., and Turpin, D. H.: Respiratory losses in the light in a marine diatom: Measurements by short-term mass spectrometry, Limnol. Oceanogr., 34, 11531161, 1989. 